\title{
The montage in the Chinese poetry
}

\author{
Yanming Sun \\ News Broadcast Institute \\ HuangHe Science and Technology College \\ Zhenghzou, China
}

\begin{abstract}
-we can read film montage anywhere in great Chinese poetry. We can also find the charm of Chinese poetry in the film montage. The reason is that the both are very common in the language structure and the figures of speech. Whether narrative, expressing emotions and thought or metaphor, contrast and symbol or compression, amplification, crisscross and stream-of-consciousness and so on, all these are artistic thoughts. Their forms of thinking are the same or very similar. That is an amazing artistic realm. It is very worth further studying. It is very instructive for us to learn the creation of films and TV plays. Let's read the classic carefully! Reading is always beneficial.
\end{abstract}

\section{Keywords—poetry; picture; montage}

Chinese poetry is not only like a vast sea but has extensive knowledge and profound scholarship as well. Classics are dazzling. They are of ingenious sentences, magnificent pictures, wonderful artistic conception and deep thoughts, which often make people feel amazed .However, what does Chinese poetry have to do with the Russian film montage? Can montages be found in the Chinese poetry? Or can Chinese poetry be seen in montages?

The former Soviet montage theorist, Eizenshtein had ever found out the rational of montage from the image of Chinese characters. Now let's share his research achievement. For instance, “口”plus “犬”makes “吠”, “口”plus “乌”甶”年es “鸣”and“口”plus “口”plus“口”makes “品”; Again such as: the character “马” exists in “骑, 驰, 骋, 骏, 瀷, 驱” and so on. These characters remain the meaning of “马”(a horse). There is a horse standing there. One instance and then the lines, “泪” (tears) consists of 8 (water) and 目 (eyes). This character is the image of eyes with tears. And the character “聼”(listen) is also the image of a door with an ear next to it. And another character “忍” (endure) is just like a heart with a knife into it. All these correspond to Eizenshtein's montage theory, a scene with a scene is equal to the thought. He advocated that scenes should be processional, in conflict, compared, metaphorical and symbolic. That is "one plus one is over two", which we all know. In this way, can we grasp montage in the Chinese poetry? Of course, we can. There are a number of examples in Chinese "The Book of Odes".

"The Book of Odes" is the first anthology of poetry in China, which is composed by "Feng", "Ya" and "Song"and laid the foundation of creating poetry in China. "Feng, Ya,Song" constitutes the form of Chinese poetry, while "Fu,Bi,Xing" constitutes the artistry of Chinese poetry.
The poetry by later generations is deeply influenced by "The Book of Odes". As is known to all, "Fu" means stating something directly, portraying it and expressing emotions. "Bi" means drawing an analogy and metaphor. "Xing" means intoning after statement. These are really similar to montage technique of expression.

"The Book of Odes" wins universal praise and lasts through the ages because of its beauty of the sentences, rhythms, artistic conceptions and tones.

Now let's appreciate the poem that people never tire of reading, "Crying Ospreys". "Merrily the ospreys cry, On the islet in the stream. Gentle and graceful is the girl, A fit wife for the gentleman." Here we can see a vivid scene-On a green islet in a stream, there are two ospreys singing face to face. I see a pretty girl standing by a stream. She is just my dream lover(Paraphrased by the writer). Its sentences are concise and fluent, the picture is beautiful and moving, the artistic conception is intriguing and the emotion is pristine and implicit. Here are its frames:

Frame 1: On the green islet in the stream, there are two ospreys singing face to face.

Frame 2: By the small river, a pretty is doing some washing while a handsome young man is staring at her infatuatedly.

The two frames form a metaphorical montage sentence.

In films or TV plays, creators would like to compare scenes by frame to express their certain moral figuratively and implicitly. In this way, they are able to highlight the similar feature between two different events. This can make audiences associate and comprehend their morals, and then the audiences can appreciate the emotional coloring of the events. A former Soviet great master of montage, Pudovkin succeeded in using this technique in the film "Mother" by him.

Frame1: There are a crowd of workers holding a demonstration.

\section{Frame 2: The ice in the river is thawing.}

The combine two scenes brought about a new meaning. When the tide of revolution is coming, the frozen river begins to thaw. The method is just like the writing technique, "Bi" in "the Book of Odes".

Poetry can not do without an artistic conception. An artistic conception can not do without a picture. A picture can 
not do without lingering charm. This is the revelation that we gain from the classic in "the Book of Odes". Literary thinking must be a kind of thinking in images, while we should pursue the beauty of artistic conceptions, the beauty of images, the beauty of pictures and the beauty of rhyme.

The film and television thinking is a direct sound and picture art thinking, which has a lot in common with poetry. Poetry exists in a beautiful picture, and a beautiful picture exists in poetry.

This can be confirmed in another poem in "the Book of Odes". For instance, "Reeds" "By the river bank lush reeds grow, covered in dew white as snow; The beauty I want to know, is somewhere along the river flow;" Here we can see a pathos picture appearing on the paper: A lot of green reeds are growing by the river. In the late autumn, they are covered in hoarfrost. Oh, my lover, where are you? You are far away from me along the river (paraphrased by the writer).

In "Reeds", scene blend shows the writer's feeling of missing his lover.

Another example, in “Caiwei”, there are very great classic sentences: "At first, when we set out, The willows are fresh and green; Now when we shall be returning, The snow will be falling clouds; Long and tedious will be our marching; We shall hunger, we shall thirst. Our hearts are wounded with grief, and no one knows our sadness."

Let's catch the meaning of the poem. "When I left for the army, the green willows were blowing in the wind. Today I'll be returning when it is snowing heavily. There is lot of snow on the ground and the road is muddy, so I'm having a lot of trouble walking on. However, I am exhausted because of hunger and thirst. I am moved by what I see. Whom shall I tell about the sadness?(paraphrased by the writer).

The poet uses both the technique of comparative montage and the technique of lyrical montage in it. We can not only the see comparison situation now and then but realize the old soldier's painful feeling. As time goes by, the war is still going on, so it is hard to return home. Here are two scenes, one scene, the green willows are blowing in the wind, and the other, it is snowing heavily. The two pictures condense the ages skillfully. However, the old soldier's aching heart is set off by the heavy snow. The scene is more miserable. Not only the poem but also the picture is moving. The lively description makes a perfect visual effect.

In the flourishing Tang Dynasty, the Chinese poetry culminated. It has been a very valuable treasure in Chinese literature.

“Jueju” by the great poet, Du Fu:

In the green willow two yellow orioles sing up,

Into the blue sky a flock of white egrets fly up.

The snow-capped peak of Mount West is framed in my window.

The boats faraway from Wu moor close by my door.

Really one step brings out one scene, and one sentence is a picture. It's no wonder that film theorists regard it as a classic of montage.

The poetic genius Libai's quatrain, "Watching the waterfall on Mount Lu"

The sunlit Censer peak exhales a wreath of cloud;

Like an upended stream cataract sounds loud.

Its torrent dashes down three thousand feet from high;

As if the Silver River fell from azure sky.

Each lively picture brings us a wonderful reverie and joy.

The Hyangnobong in Mount $\mathrm{Lu}$ is very high and wonderful.In the bright sunshine, a wreath of cloud is rising, and the waterfall is dashing down and spraying here and there. It is just like the Milky Way falling from the space. Readers are moved by the wonderful imagination and romantic style. This is the association montage. The writer associates the Milky Way with the waterfall. The association is from micro to macro. It is a very big leap of thinking, which just is one of the highly free time and space features in modern montage.

The landscape poet, Wangwei's famous works, “ Autumn Evening in the Mountains":

After fresh rain in the mountains bare

Autumn permeates evening air.

Among pine-trees bright moonbeams peer

Over crystal stones flows water clear.

Bamboos whisper of washer-maids;

Lotus sties when fishing boat wades.

Though fragrant spring may pass away,

Still here's the place for to stay.

We can read fresh pictures, meaningful artistic conceptions and implicative ideas in the poem. Readers are never tired of reading it and get nice taste in it.

The bare mountains after rain, the autumn view in the evening, the moonlight in pine-trees and the water over stones, all the pictures produce an integrated effect. But suddenly the washer-maids spread out tinkling laughter in the bamboos and break down quiet. The rowing oars, floating boats and blowing lotus on the water, these pictures produce a special effect. The sound leads to the lively pictures. This style richens the meaning of the pictures and the pictures are really true to life.

For "off camera"in films and TV, we often use sounds to create pictures. This can get wonderful effects. In the film "My parents" by Zhang yi-mo, he uses this skill several times. The children with Mr. Luo are reading books loudly. This scene always makes people image and affects our emotion. The mother listen to the children reading for over forty years. Audiences remain in the memory of listening for long time.

"Fu" in the Book of Odes is stating something directly, describing something and expressing our emotion. And in 
films, The main aim of narrative montage is telling details of stories and showing events The frames are divided and combined by the process of events, logical order, causal relationship paragraphs and situation. Both of the techniques are very similar. For example, the first passage of "The Faithless Man" in "Guo Feng, Wei Feng":

A man seemed free from guile,

In trade he wore a smile,

He'd barter cloth for thread;

No, to me He'd be wed.

We went across the ford;

I'd not give him my word.

I said by hillside green,

"You have no go between.

Try to find one, I pray.

In autumn be the day! ',

This is a passage of telling a full story. A good-natured young man exchanges cloth for thread. In fact, he want to talk about his wedding instead of trading. I take him across Qi Rever and we walk until the hill. But I'd not delay the wedding. He should ask a matchmaker to come with him. I said to him, "Be angry with me, we'll have a wedding this autumn."(paraphrased by the writer).

The technique of narrative montage is used in this passage to tell the story clearly. It is unnecessary to go into details. So the frames can be edited according to the chronological order and the plot development order. Narrative montage of complex sentences are used here to express the girl's promising the young man to marry him in autumn. It is the present continue tense ( They are talking while walking) + the future tense ( They will get marry this autumn)+the present continue tense(The young man is smiling happily).

In the famous poem "The Officials in Stone Village" by the great poet Dufu. The writing skill, "Fu" is used:

In Stone Village I put up for the night,

The officials are catching men at night.

The old man climbs over the wall to run away,

The old lady covers for him at the gate in fright.

Dufu was famous as a great realist poet in China. The poem by him showed the reality. It was in the Rebellion of Anshi. The country and homes were broken, there were disaster victims everywhere and the people can hardly live. We can realize the technique of film narrative montage in his poem. And now let's divide the first passage of the poem into five frames.

Frame1: The dismissal $\mathrm{Du}$ is walking on the path hurriedly.

Frame2: It is late evening in Stone Village.

Frame3: The officials are catching men here and there when Du gets to the village.

Frame4: The old man climbs over the wall to escape. fear.

Frame5: The old lady covers for her husband at the gate in

Though the main frame is what Du saw in this passage, the time line is used in series with the plots. So this is just the narrative montage that is often used in films. Its advantage is telling a story very clearly. This kind of technique fits not only documentaries but also the films and TV plays with documentary style. Of course, the narrative and expression are both used in films and TV plays. We read Chinese poetry and learn creating skills of montage from so many famous poems so that our productions of film and television can be richened.

"Bi" in "the Book of Odes" means drawing an analogy and metaphor, and "Fu" refers to intoning after statement. As I understand, these two writing techniques include three kinds of rhetoric. They're analogy, metaphor and comparing.

The main passage of "The Faithless Man" in Wei Feng reflects the rhetoric more synchronously.

How fresh were mulberries

With their fruit on the trees!

Beware, O turtledove,

At not the fruits you love,

For they'll intoxicate.

Do not repent too late!

Man may do what they will,

He can stone it still.

The wrong a woman's done

No man will e'er condone.

The mulberries appear

With yellow leaves and sear.

'er since he married me,

I've shared his poverty.

Desert'd, from him I part,

The flood has wet my cart.

I have done nothing wrong;

He changes all along.

He's fickle to excess,

Capricious, pitiless.

Now let me explain the two passages of the poem:

When mulberry leaves are growing on, the tree is of profusion and green. Oh turtledove, don't eat the fruits on the mulberry tree. The boy's love for the girl is rather changeable, but the girl's love for the boy is fixed. 
When mulberry leaves fall down, the tree is brown and unviable. Since I married him three years ago, I have lived in poverty and suffered from hunger. Now I part from him and desert to my own home across Qihe River. The water is so deep that my cart is all wet. The man behaved with bad manners, and his love is of two minds. (Paraphrased by the writer)

Obviously, the mulberries leaves are not use to describe the view but to give a symbol. They symbolize the ups-and-downs of the girl's fate and changes of their emotions. It takes a short while to change their responsible childhood love to treachery. How sorrow it is!

We are able to see not only the montage metaphor role but the montage contrast effect as well in the two passages.

In brief, I think we can read film montage anywhere in great Chinese poetry. We can also find the charm of Chinese poetry in the film montage. The reason is that the both are very common in the language structure and the figures of speech. Whether narrative, expressing emotions and thought or metaphor, contrast and symbol or compression, amplification, crisscross and stream-of-consciousness and so on, all these are artistic thoughts. Their forms of thinking are the same or very similar. That is an amazing artistic realm. It is very worth further studying. It is very instructive for us to learn the creation of films and TV plays. Let's read the classic carefully! Reading is always beneficial.

\section{REFERENCES}

[1] Li Jian, Liu Daoying, "The Book of Odes" The ancient classics library of China.

[2] Xing Wen-ruo, Su Ran, "Poetry Anthology of the Three Great Poets in Tang Dynasty"

[3] Wang Xiaohong, "TV Picture Editing”.

[4] Shao Qing-feng, Li Jun, "Audio-visual Language".

[5] Louis Giannetti, “Understanding Movies”.

[6] Ernest Lindgren, "The Art of the Film".

[7] "The Art of montage" http://baike. Baidu.com/view/1870091.htm 